\title{
Hydrogen sulphide removal from biogas by an anoxic biotrickling filter packed with Pall rings
}

\author{
Maikel Fernández a ${ }^{\text {, Martín Ramírez }}{ }^{\mathrm{a}, *}$, Rosa María Pérez ${ }^{\mathrm{b}}$, José Manuel Gómez ${ }^{\mathrm{a}}$, Domingo Cantero a \\ ${ }^{a}$ Department of Chemical Engineering and Food Technologies, Faculty of Sciences, University of Cádiz, Campus de Excelencia Internacional Universitario ceiA3, Puerto Real, \\ Cádiz, Spain \\ ${ }^{\mathrm{b}}$ Study Centre of Industrial Biotechnology, Faculty of Natural Sciences, East University, Santiago de Cuba, Cuba
}

\section{H I G H L I G H T S}

- ORP measurement can be used for nitrate supply control.

- Biogas desulphurization was achieved without a reduction in methane concentration.

- A high $\mathrm{EC}_{\mathrm{CRIT}}$ of $120 \mathrm{~g} \mathrm{~S} \mathrm{~m}^{-3} \mathrm{~h}^{-1}$ can be achieved using polypropylene Pall rings.

\section{A R T I C L E I N F O}

\section{Article history:}

Received 29 January 2013

Received in revised form 19 March 2013

Accepted 4 April 2013

Available online 13 April 2013

\section{Keywords:}

Pall rings

Hydrogen sulphide

Biogas

Anoxic biofiltration

Biotrickling filter

\begin{abstract}
A B S T R A C T
Hydrogen sulphide $\left(\mathrm{H}_{2} \mathrm{~S}\right)$ is one of the most problematic contaminants in biogas. In this study, a biotrickling filter with a working volume of $2.4 \mathrm{~L}$ and packed with polypropylene Pall rings was tested for its ability to remove $\mathrm{H}_{2} \mathrm{~S}$ from biogas under anoxic conditions. The influence of the $\mathrm{H}_{2} \mathrm{~S}$ inlet concentration, nitrate feeding regime (manual and controlled) and liquid flow rate on the elimination capacity of the biotrickling filter was studied. The results indicate that $99 \%$ of the $\mathrm{H}_{2} \mathrm{~S}$ was removed for $\mathrm{H}_{2} \mathrm{~S}$ inlet loads lower than $120 \mathrm{~g} \mathrm{~S} \mathrm{~m}^{-3} \mathrm{~h}^{-1}$ when using controlled nitrate feeding by ORP.
\end{abstract}

(C) 2013 Elsevier B.V. All rights reserved.

\section{Introduction}

The use of biogas, generated in anaerobic digesters, as an energy source contributes to the reduction of greenhouse gas emissions. However, biogas often contains hydrogen sulphide $\left(\mathrm{H}_{2} \mathrm{~S}\right)$ at high concentrations $(0.1-2 \%)$, and this concentration depends mainly on the raw material used in the digester. $\mathrm{H}_{2} \mathrm{~S}$ has the potential to cause corrosion damage to combustion engines and can have adverse environmental effects due to the sulphur oxide emissions it produces [1].

Biogas purification methods can be classified into two generic categories: those involving physicochemical phenomena (reactive or non-reactive absorption, reactive or non-reactive adsorption) and those involving biological processes $\left(\mathrm{H}_{2} \mathrm{~S}\right.$ biodegradation by microorganisms to give less harmful forms) [2].

The physicochemical methods for $\mathrm{H}_{2} \mathrm{~S}$ removal are expensive and generate waste, so biological processes have become a viable

\footnotetext{
* Corresponding author. Tel.: +34 956016474; fax: +34 956016411.

E-mail address: martin.ramirez@uca.es (M. Ramírez).
}

alternative from both economic and environmental points of view. Current biological processes for the removal of $\mathrm{H}_{2} \mathrm{~S}$ present in gaseous effluents are generally based on aerobic methods. However, there are few studies concerning anoxic single-stage processes for $\mathrm{H}_{2} \mathrm{~S}$ removal from biogas. Typically, an aerobic biological process requires a stoichiometric oxygen level (approximately 5\% depending the $\mathrm{H}_{2} \mathrm{~S}$ inlet concentration). For safety reasons, it is necessary to control the oxygen dosage in order to avoid reaching high oxygen concentrations because the lower and upper explosive limits for methane are $5 \%$ and $15 \%$, respectively [3]. In aerobic processes air is mixed with the biogas and this leads to a dilution of the methane concentration [4,5]. Anoxic systems, in comparison with aerobic systems, do not suffer from the two aforementioned operational problems.

Studies on the elimination of $\mathrm{H}_{2} \mathrm{~S}$ under anoxic conditions in gaseous effluents have started to appear in the literature in recent years $[3,6,7]$. This process is based on autotrophic denitrification, in which specific denitrifying bacteria carry out a dual process referred to as 'disimilatory nitrate reduction' in the presence of sulphide, as shown in the global Eq. (1) [7]. 


\section{Nomenclature}

$\mu_{\mathrm{G}} \quad$ viscosity of gas phase $\left(\mathrm{kg} \mathrm{m}^{-1} \mathrm{~h}^{-1}\right)$

$\mu_{\mathrm{L}} \quad$ viscosity of liquid phase $\left(\mathrm{kg} \mathrm{m}^{-1} \mathrm{~h}^{-1}\right)$

$a_{\mathrm{t}} \quad$ total surface area of packing material $\left(\mathrm{m}^{2} \mathrm{~m}^{-3}\right)$

$a_{\mathrm{w}} \quad$ wetted surface area $\left(\mathrm{m}^{2} \mathrm{~m}^{-3}\right)$

$D_{\mathrm{G}} \quad$ diffusivity in gas phase $\left(\mathrm{m}^{2} \mathrm{~h}^{-1}\right)$

$D_{\mathrm{L}} \quad$ diffusivity in liquid phase $\left(\mathrm{m}^{2} \mathrm{~h}^{-1}\right)$

$D_{\mathrm{p}} \quad$ nominal size of packing material (m)

$g \quad$ gravitational constant $\left(\mathrm{m} \mathrm{h}^{-2}\right)$

$G \quad$ superficial mass velocity of gas $\left(\mathrm{kg} \mathrm{m}^{-2} \mathrm{~h}^{-1}\right)$
$k_{\mathrm{G}} \quad$ gas film mass transfer coefficient in the Onda correlation $\left(\mathrm{kmol} \mathrm{m}^{-2} \mathrm{~h}^{-1} \mathrm{~atm}^{-1}\right)$

$K_{\mathrm{L}} \quad$ liquid film mass transfer coefficient $\left(\mathrm{m} \mathrm{h}^{-1}\right)$

$\mathrm{L} \quad$ superficial mass velocity of liquid $\left(\mathrm{kg} \mathrm{m}^{-2} \mathrm{~h}^{-1}\right)$

$R \quad$ gas constant $\left(\mathrm{m}^{3} \mathrm{~atm}^{-1} \mathrm{~mol}^{-1} \mathrm{~K}^{-1}\right)$

$T \quad$ absolute temperature $(\mathrm{K})$

$\rho_{\mathrm{G}} \quad$ density of gas phase $\left(\mathrm{kg} \mathrm{m}^{-3}\right)$

$\rho_{\mathrm{L}} \quad$ density liquid phase $\left(\mathrm{kg} \mathrm{m}^{-3}\right)$

$$
\begin{aligned}
15 \mathrm{NO}_{3}^{-}+12 \mathrm{H}_{2} \mathrm{~S} \rightarrow & 9 \mathrm{H}_{2} \mathrm{O}+6 \mathrm{~S}^{0}+6 \mathrm{SO}_{4}^{-2}+5 \mathrm{NO}_{2}^{-}+5 \mathrm{~N}_{2} \\
& +2 \mathrm{OH}^{-}+4 \mathrm{H}^{+}
\end{aligned}
$$

Previously, we studied a biotrickling filter packed with open polyurethane foam (OPUF) using nitrate-reducing and sulphideoxidizing bacteria (NR-SOB) as the inoculum. In this process a removal efficiency (RE) of $99 \%$ was obtained when working under the following conditions: inlet loads below $130 \mathrm{~g} \mathrm{~S} \mathrm{~m}^{-3} \mathrm{~h}^{-1}$, a programmed nitrate feeding regime, temperature of $30^{\circ} \mathrm{C}, \mathrm{pH}$ between 7.4 and 7.5 and trickling liquid velocity (TLV) between 5 and $15 \mathrm{~m} \mathrm{~h}^{-1}$ (data not published). The main advantages of anoxic biotrickling filters versus conventional aerobic biotrickling filters are that the biogas is not diluted with nitrogen and there is no oxygen mass transfer limitation (nitrate is dissolved in the medium). Therefore this technology is highly feasible as a pre-treatment for $\mathrm{H}_{2} \mathrm{~S}$ removal from biogas for biogas pipe grade quality depuration.

In the study described here, OPUF was replaced with polypropylene Pall rings to test the feasibility of this carrier as a packing material. Pall rings are commonly used as supports in chemical scrubbers [8] due to their low pressure drop values with high flows of gas and liquid. Pall rings have a smaller surface area than other conventional carriers used in biotrickling filters, such as OPUF [9], so they are less susceptible to pressure loss related to the accumulation of sulphur (formed by the incomplete oxidation of sulphide) and biomass.

The goal of this study was to evaluate the feasibility of using polypropylene Pall rings as carriers for NR-SOB immobilisation in anoxic $\mathrm{H}_{2} \mathrm{~S}$ removal processes. The influence of $\mathrm{H}_{2} \mathrm{~S}$ inlet concentration, nitrate feeding regime (manual and controlled) and liquid flow rate in anoxic biofiltration were considered.

\section{Materials and methods}

\subsection{Nutrient solution}

The mineral medium employed was adapted from ATCC-1255 Thiomicrospira denitrificans medium. The mineral medium contained $\left(\mathrm{g} \mathrm{L}^{-1}\right)$ : $\mathrm{KH}_{2} \mathrm{PO}_{4}, 2 ; \mathrm{NH}_{4} \mathrm{Cl}, 1, \mathrm{MgSO}_{4} \cdot 7 \mathrm{H}_{2} \mathrm{O}, 0.8$; $\mathrm{NaNO}_{3}$, ranged between 5 and 10 ; iron solution, $1 \mathrm{~mL}$; trace element solution (SL-4), $2 \mathrm{~mL}$. The iron solution was prepared dissolving $0.2 \mathrm{~g}$ of $\mathrm{FeSO}_{4} \cdot 7 \mathrm{H}_{2} \mathrm{O}$ in $100 \mathrm{~mL}$ of $\mathrm{H}_{2} \mathrm{SO}_{4}$ solution $(0.1 \mathrm{~N})$. The SL- 4 composition was $\left(\mathrm{g} \mathrm{L}^{-1}\right)$ : EDTA, 0.5; $\mathrm{FeSO}_{4} \cdot 7 \mathrm{H}_{2} \mathrm{O}, 0.2$; trace element solution (SL-6), $100 \mathrm{~mL}$. The SL-6 composition was $\left(\mathrm{g} \mathrm{L}^{-1}\right)$ : $\mathrm{ZnSO}_{4} \cdot 7 \mathrm{H}_{2} \mathrm{O}$, $0.1 ; \mathrm{MnCl}_{2} \cdot 4 \mathrm{H}_{2} \mathrm{O}, 0.03 ; \mathrm{H}_{3} \mathrm{BO}_{3}, 0.3 ; \mathrm{CoCl}_{2} \cdot 6 \mathrm{H}_{2} \mathrm{O}, 0.2 ; \mathrm{CuCl}_{2} \cdot 2 \mathrm{H}_{2} \mathrm{O}$, $0.01 ; \mathrm{NiCl}_{2} \cdot 6 \mathrm{H}_{2} \mathrm{O}, 0.02 ; \mathrm{Na}_{2} \mathrm{MoO}_{4} \cdot 2 \mathrm{H}_{2} \mathrm{O}, 0.03$. The $\mathrm{pH}$ was adjusted to 7.0 with $\mathrm{NaOH}(2 \mathrm{~N})$. This medium was referred to as modified mineral medium (M3).

\subsection{Inoculum and carrier materials}

The inoculum was obtained from biomass immobilised in OPUF units that were previously used in biotrickling filter studies $[4,10]$.
Ten OPUF cubes measuring $8 \mathrm{~cm}^{3}$ were submerged in $1 \mathrm{~L}$ of M3 and then given ultrasonic treatment for 15 min to achieve microorganism desorption. The biomass concentration after the desorption process was $2.44 \pm 0.05 \times 10^{8}$ cell $\mathrm{mL}^{-1}$. This previous inoculum was mixed with $1 \mathrm{~L}$ of $\mathrm{M} 3\left(\mathrm{NaNO}_{3}\right.$ concentration of $\left.5 \mathrm{~g} \mathrm{~L}^{-1}\right)$ and the $2 \mathrm{~L}$ sample was inoculated in the biofilter.

Polypropylene Pall rings, measuring $5 / 8^{\prime \prime}$ in diameter (Pall Ring Company, UK), were used as the carrier material (a total weight of $220.2 \mathrm{~g}$ ). This carrier had a density of $110 \mathrm{~kg} \mathrm{~m}^{-3}$ and a specific surface of $320 \mathrm{~m}^{2} \mathrm{~m}^{-3}$.

\subsection{Experimental setup and methodology}

The experimental setup is shown in Fig. 1. The biotrickling filter, which had a working volume of $2.4 \mathrm{~L}$, was built from a $110 \mathrm{~mm}$ diameter PVC column. A PVC end cap with small perforations was used as the liquid distribution system. The biogas was produced on site from two $200 \mathrm{~L}$ upflow anaerobic sludge blanket (UASB) reactors and the $\mathrm{H}_{2} \mathrm{~S}$ concentration was increased with an $\mathrm{H}_{2} \mathrm{~S}$ generation system [11]. A Digital Multimeter 44 (CRISON, Spain) was used for $\mathrm{pH}$ control (7.4-7.5) with the addition of $\mathrm{NaOH}$ $(2.0 \mathrm{~N})$ and oxidation-reduction potential (ORP) measurement. The room temperature was controlled between 28 and $30^{\circ} \mathrm{C}$.

The liquid flow rate of the nutrient solution and biogas flow rate were controlled by variable area rotameters, with the liquid flow rate maintained between 20 and $180 \mathrm{~L} \mathrm{~h}^{-1}$ (ABB D10A11 model, Spain), and the biogas flow rate was maintained between 8.4 and $60.0 \mathrm{~L} \mathrm{~h}^{-1}$ (ABB A6131 model, Spain).

Two regimes for nitrate supply were tested: manual dosage before nitrate depletion (manual regime, from day 0 to 27) and automatic dosage by ORP measurement (controller regime, from day 27 to 104 ). In the manual regime the nitrate concentration was measured ex situ according to the analytical procedure described in Section 2.5 . $50 \%$ of the recirculation volume $(1 \mathrm{~L})$ was changed for M3 medium with $10 \mathrm{~g} \mathrm{~L}^{-1}$ of $\mathrm{NaNO}_{3}$ when the nitrate concentration fell below $20 \mathrm{mg} \mathrm{L}^{-1}$. In the controlled regime the ORP was measured on-line. Sulphide accumulation produced a significant decrease in the ORP $[12,13]$ and $\mathrm{M} 3$ solution $\left(\mathrm{NaNO}_{3}\right.$ concentration of $5 \mathrm{~g} \mathrm{~L}^{-1}$ ) was added between the following setpoints: -260 and $-250 \mathrm{mV}$ for an IL lower than $80 \mathrm{~g} \mathrm{~S} \mathrm{~m}^{-3} \mathrm{~h}^{-1}$ and between -320 and $-300 \mathrm{mV}$ for higher ILs. The recirculation volume was kept constant with a siphon.

Biofilm formation was performed in situ in the biotrickling filter under the manual regime. During the first 15 days the $\mathrm{H}_{2} \mathrm{~S}$ inlet concentration was zero in order to remove the elemental sulphur added with the inoculum (sulphur cleaning period).

The biogas flow rate, $\mathrm{H}_{2} \mathrm{~S}$ concentration, $\mathrm{H}_{2} \mathrm{~S}$ inlet load (IL) and TLV ranged from 8.4 to $60.0 \mathrm{~L} \mathrm{~h}^{-1}, 1400$ to $14,600 \mathrm{ppmv}, 9$ to $201 \mathrm{~g} \mathrm{~S} \mathrm{~m}^{-3} \mathrm{~h}^{-1}$ and 2.28 to $20.56 \mathrm{~m} \mathrm{~h}^{-1}$, respectively. Three shutdowns of the recirculation flow were programmed on days 61, 78 and 89 in order to check the effect on RE and recovery time. 


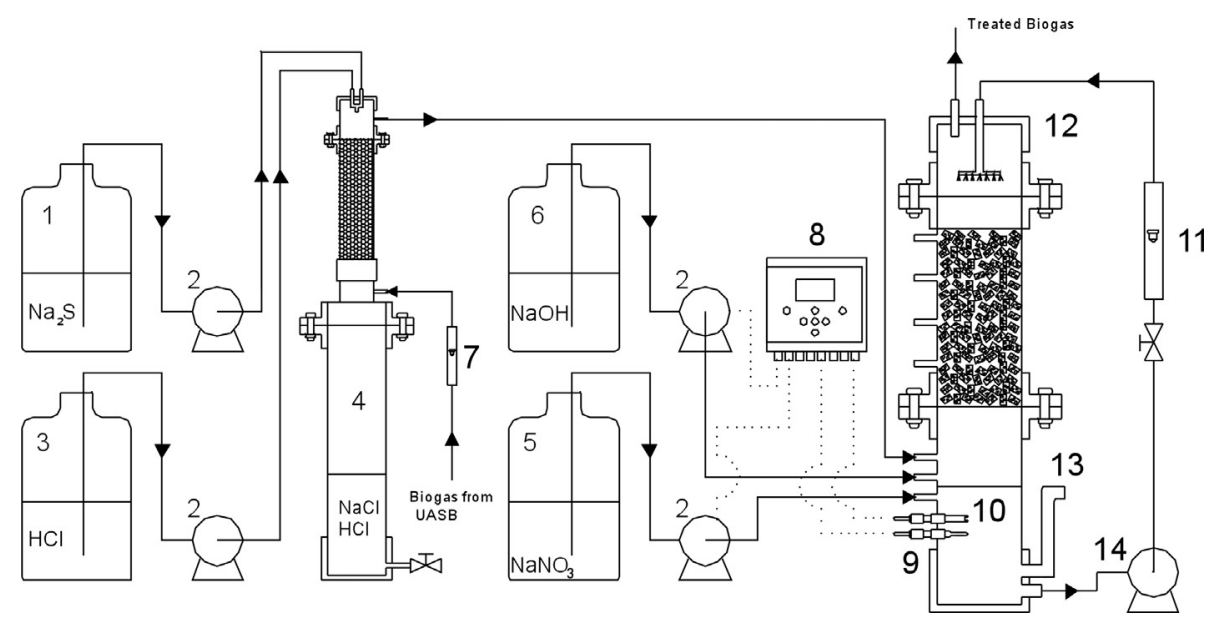

Fig. 1. Experimental installation setup. (1) $\mathrm{Na}_{2} \mathrm{~S}$ container, (2) Peristaltic pump, (3) $\mathrm{HCl}$ container, (4) $\mathrm{H}_{2} \mathrm{~S}$ generation tower, (5) nutrient solution container, (6) NaOH container, (7) Gas rotameter, (8) Multimeter 44, (9) pH electrode, (10) ORP electrode, (11) liquid rotameter, (12) biotrickling filter, (13) siphon, and (14) MP-15R magnetic water pump.

\subsection{Estimation of mass transfer coefficients}

The Onda equation [14] was used to calculate the gas film mass transfer coefficient $\left(K_{\mathrm{G}}\right)$ and liquid film mass transfer coefficient $\left(K_{\mathrm{L}}\right)$ as follows:

$\frac{K_{\mathrm{G}} R T}{a_{\mathrm{t}} D_{\mathrm{G}}}=5: 23 \quad \frac{G}{a_{\mathrm{t}} \mu_{\mathrm{G}}}{ }^{0: 7}{\frac{\mu_{\mathrm{G}}}{\rho_{\mathrm{G}} D_{\mathrm{G}}}}^{1=3}\left(a_{\mathrm{t}} D_{\mathrm{p}}\right)^{-2: 0}$

$K_{\mathrm{L}}{\frac{\rho_{\mathrm{L}}}{\mu_{\mathrm{L}} g}}^{1=3}=0: 0051{\frac{L}{a_{\mathrm{w}} \mu_{\mathrm{L}}}}^{2=3}{\frac{\mu_{\mathrm{L}}}{\rho_{\mathrm{L}} D_{\mathrm{L}}}}^{-0: 5} a_{\mathrm{t}} D_{\mathrm{p}}{ }^{0: 4}$

The wetted surface area $\left(a_{\mathrm{w}}\right)$ and total surface area $\left(a_{\mathrm{t}}\right)$ were considered equal. The Table 1 shows the values used.

The viscosity of the biogas was estimated according to the procedure 11B2.1 for gaseous mixtures at low pressure [15] and the diffusivity of $\mathrm{H}_{2} \mathrm{~S}$ in the biogas $\left(D_{\mathrm{L}}\right)$ phase was calculated according the theory of diffusion in binary gas mixtures at low pressures considered the ideal gas law [17].

\subsection{Analytical methods}

The quantity of immobilised biomass was measured according to the counting method described by Gómez et al. [19]. The concentration was expressed as cells per gram of carrier and was determined by counting the number of bacteria on a unit of the carrier material and dividing the total quantity of biomass by the

Table 1

Parameters used to calculate the mass transfer coefficients.

\begin{tabular}{lll}
\hline Parameters & Value & Refs. \\
\hline$\mu_{\mathrm{G}}\left(\mathrm{kg} \mathrm{m}^{-1} \mathrm{~h}^{-1}\right)$ & $6.79 \times 10^{-2}$ & {$[15]$} \\
$\mu_{\mathrm{L}}\left(\mathrm{kg} \mathrm{m}^{-1} \mathrm{~h}^{-1}\right)$ & 2.87 & {$[16]$} \\
$a_{\mathrm{t}}\left(\mathrm{m}^{2} \mathrm{~m}^{-3}\right)$ & 320 & Supplier \\
$a_{\mathrm{w}}\left(\mathrm{m}^{2} \mathrm{~m}^{-3}\right)$ & 320 & Supposed \\
$D_{\mathrm{G}}\left(\mathrm{m}^{2} \mathrm{~h}^{-1}\right)$ & $1.49 \times 10^{-5}$ & {$[17]$} \\
$D_{\mathrm{L}}\left(\mathrm{m}^{2} \mathrm{~h}^{-1}\right)$ & $7.45 \times 10^{-6}$ & {$[18]$} \\
$D_{\mathrm{p}}\left(\mathrm{m}^{-1}\right)$ & $5.12 \times 10^{-3}$ & This study \\
$g\left(\mathrm{~m} \mathrm{~h}^{-2}\right)$ & $1.27 \times 10^{8}$ & {$[16]$} \\
$G\left(\mathrm{~kg} \mathrm{~m}^{-2} \mathrm{~h}^{-1}\right)$ & 6.97 & This study \\
$L\left(\mathrm{~kg} \mathrm{~m}^{-2} \mathrm{~h}^{-1}\right)$ & $2247-20472$ & This study \\
$R\left(\mathrm{~m}^{3} \mathrm{~atm}^{-1} \mathrm{~mol}^{-1} \mathrm{~K}^{-1}\right)$ & $8.20 \times 10^{-5}$ & {$[16]$} \\
$T(\mathrm{~K})$ & 303 & This study \\
$\rho_{\mathrm{G}}\left(\mathrm{kg} \mathrm{m}^{-3}\right)$ & 1.02 & This study \\
$\rho_{\mathrm{L}}\left(\mathrm{kg} \mathrm{m}^{-3}\right)$ & 995.65 & {$[16]$} \\
\hline
\end{tabular}

weight of the Pall ring. The sulphate, nitrate and nitrite concentrations in the recirculation medium were determined daily. The sulphate concentration was measured using the turbidimetric method $\left(4500-\mathrm{SO}_{4}^{2-}\right.$ E) [20], and the nitrite and nitrate concentrations were analysed using a Spectroquant ${ }^{\circledR}$ Pharo 300 spectrophotometer (Merck, Darmstadt, EU) by the colorimetric method $\left(4500-\mathrm{NO}_{2}^{-}\right.$ B) and ultraviolet spectrophotometric screening method (4500$\mathrm{NO}_{3}^{-} \mathrm{B}$ ), respectively [20]. The sulphide concentration was obtained with the 1-88 NANOCOLOR ${ }^{\circledR}$ kit (Macharey-Nagel, Germany).

A specific digital sensor (GasBadge ${ }^{\circledR}$ Pro, Industrial Scientific, UK) was used to measure the $\mathrm{H}_{2} \mathrm{~S}$ concentration from 0 to 500 ppmv. A GA2000Plus gas analyser (Fonotest Instruments S.L., Spain) equipped with an external electrochemical $\mathrm{H}_{2} \mathrm{~S}$ gas sensor was used to measure the $\mathrm{H}_{2} \mathrm{~S}$ concentration from 500 to 5000 ppmv and $\mathrm{CH}_{4}$ and $\mathrm{CO}_{2}$ concentrations by infra-red absorption (measured daily). $\mathrm{H}_{2} \mathrm{~S}$ concentrations greater than 5000 ppmv were analysed using a gas chromatograph (450-GC, Bruker, Spain) equipped with a thermal conductivity detector (TCD).

The complete DNA of the biomass was extracted using an UltraClean Soil DNA Isolation Kit (Mo Bio Laboratories Inc., USA) according to the manufacturer's instructions. The V3-V5 region of the bacterial 16S rRNA gene was PCR-amplified using VELOCITYTM DNA Polymerase and primers GC-338F and 907R (Bioline, Spain). The $25 \mathrm{lL}$ reaction mixtures contained $5 \mathrm{lL}$ of $5 \mathrm{X}$ Hi-Fi Reaction Buffer (Bioline, Spain), $0.5 \mathrm{lL}$ of each primer $(10 \mathrm{lM}), 2.5 \mathrm{lL}$ of $10 \mathrm{mM}$ dNTP mix, $2 \mathrm{lL}$ of DNA, $0.75 \mathrm{lL}$ of DMSO and $0.125 \mathrm{lL}$ of $2 \mathrm{U} / \mathrm{LL}$ VELOCITYTM DNA polymerase ${ }^{\circledR}$ (Bioline, Spain) in $13.625 \mathrm{lL}$ of DNase- and RNase-free sterilised water (Promega ${ }^{\circledR}$, Spain). The PCR products were analysed by electrophoresis on $1 \%$ agarose gels in $0.5 \mathrm{X}$ TBE buffer $(100 \mathrm{mM}$ Tris, $90 \mathrm{mM}$ boric acid, $0.001 \mathrm{mM}$ EDTA) stained with $\mathrm{SYBR}^{\circledR}$ Gold nucleic acid gel stain (Bioline, Spain) to confirm the product size and estimate the DNA concentration.

The PCR products were evaluated with DGGE using the Dcode ${ }^{\mathrm{TM}}$ Universal Mutation Detection System (BioRad, USA). The DNA samples were loaded onto $8 \%(\mathrm{w} / \mathrm{v})$ polyacrylamide gels and run in $1 \mathrm{X}$ TAE (40 mM Tris, pH 8.0, $20 \mathrm{mM}$ acetic acid, $1 \mathrm{mM}$ EDTA). The polyacrylamide gels were made with a denaturing gradient from $30 \%$ to $60 \%$ (where $100 \%$ denaturant contained $7 \mathrm{M}$ urea and $40 \%$ formamide). Electrophoresis was performed at $60^{\circ} \mathrm{C}$ and $75 \mathrm{~V}$ for $17 \mathrm{~h}$. After electrophoresis, the gel was stained with $\mathrm{SYBR}^{\circledR}$ Gold nucleic acid gel stain (Bioline, Spain) according to the manufacturer's instructions. The Gel Documentation Systems ImagenQuant 100 GE Healthcare ${ }^{\circledR}$ was used to document the gels. 
A Quanta FIE 200 electron microscope (Philips) coupled to a qualitative Energy Disperse X-ray analyser (EDX) was used to obtain scanning electron microscopy images (SEM) and elemental analysis of the biofilm was performed at the end of the experiment (day 104). The samples were fixed with glutaraldehyde and dehydrated by immersion in increasing concentrations of acetone solution (50-100\%). The samples were then dried with $\mathrm{CO}_{2}$ to a critical point to remove the acetone and metallised with gold (at $15 \mathrm{~mA}$, $120 \mathrm{~s}$, and a distance of $35 \mathrm{~mm}$ ).

\section{Results and discussion}

\subsection{Biofilm formation}

The average RE was $99.5 \pm 0.6 \%$ throughout the experimental period, except for the following days: 61 (93.9\%), 78 (88\%), 89 (97.3\%), 101 (94.9\%), 103 (96.6\%) and 104 (93.3\%). The RE was high from the beginning, even immediately after starting the $\mathrm{H}_{2} \mathrm{~S}$ feeding (day 16), and this can be attributed to previous inoculum acclimation because the sample came from a biofilter with similar operational conditions. The biomass activity was high since the inoculation gave a nitrate consumption rate of $6 \mathrm{mg} \mathrm{N}-\mathrm{NO}_{3}^{-} \mathrm{L}^{-1}$ $\mathrm{h}^{-1}$ even without $\mathrm{H}_{2} \mathrm{~S}$ from the inlet (sulphur cleaning period).

The image obtained at the end of the experiment (day 104) by scanning electron microscopy (Fig. 3a) shows a carrier colonised by bacteria and sulphur. Sulphur formation was observed from the beginning of the $\mathrm{H}_{2} \mathrm{~S}$ feed (day 16). This sulphur formation may have promoted the immobilisation of bacteria on the carrier and sulphur was the main component (Fig. 3b). The biomass concentration was $1.23 \pm 0.21 \times 10^{10}$ cells (g dry carrier) ${ }^{-1}$ at 11 days. This result is quite difficult to compare with those obtained by other authors due the different properties of the packing materials (density, specific surfaces, etc.). In any case, the biomass concentrations reached in anoxic biotrickling filters were $2.4 \times 10^{5}$ cells $(\mathrm{mL} \text { of carrier })^{-1}$ with a plastic fibre carrier [6] and $1.4 \pm 0.14 \times 10^{9}$ cells (g dry carrier) ${ }^{-1}$ with OPUF [10].

\subsection{Influence of nitrate feeding regime}

Both nitrate feeding regimes studied (manual and controlled) showed high $\mathrm{H}_{2} \mathrm{~S}$ REs of $99.5 \pm 0.6 \%$, with empty bed retention times (EBRT) between 2.4 and $17.0 \mathrm{~min}$. When the manual regime was used, the nitrate added was consumed quickly and caused nitrite accumulation in the medium. Nitrate is reduced faster than nitrite, and thus, nitrite can be accumulated as an intermediate in the reduction to elemental nitrogen. Under the controlled regime nitrite and nitrate were not accumulated in the recirculation medium except on the shutdown days (Fig. 2). The controlled regime therefore allows a better performance because the biotrickling filter works under steady state conditions.

Shutdowns caused a small decrease in RE and nitrate and nitrite accumulation in the recirculation medium. The system quickly recovered to its maximum $\mathrm{RE}(99.5 \%)$ when the recirculation flow was turned back on. The instability of the system observed (RE decreased to $94.4 \%$ on day 101) was due to foam formation, which appeared when the system operated at its highest IL and TLV values. The foam was removed by the addition of a few drops of antifoaming agent. The foam formation could have resulted from the release of proteins by cell lysis under these conditions (high IL and TLV).

The use of the ORP for the nitrate supply allows optimal nitrate use, but it has the disadvantage that it is impossible to ascertain whether the $\mathrm{H}_{2} \mathrm{~S}$ accumulation in the medium (measured by the ORP decrease) was due to nitrate depletion or $\mathrm{H}_{2} \mathrm{~S}$ overload (Fig. 2, day 102).

The mean values for methane and carbon dioxide were $68 \pm 3 \%$ and $26 \pm 2 \%$, respectively. Thus, reductions in methane or carbon dioxide concentrations in the biogas were not observed. This absence of a reduction in methane concentration is a significant advantage compared to usual aerobic biotrickling filters. As a rule, in aerobic biotrickling filters air is mixed with the biogas stream to provide oxygen for the biological oxidation. Montebello et al. [4] worked with an aerobic biotrickling filter and reached a dilution factor for biogas from $6 \%$ to $32 \%$. Chaiprapat et al. [21] used a biogas-air ratio of $1: 4$ to achieve an RE of $94.7 \%$. The control of oxygen in an aerobic biotrickling filter is very important because a lack of oxygen increases clogging problems (elemental sulphur formation) and an excess of oxygen means that the biogas is severely diluted and undesired residual oxygen can be found in the biogas outlet [5]. However, the oxygen mass transfer could be improved by jet-venturi [22]. An aerated liquid recirculation at low $\mathrm{pH}$ was recently proposed by Charnnok et al. [23] in order to solve biogas dilution problems. The RE achieved by Charnnok et al. was $97.3 \%$

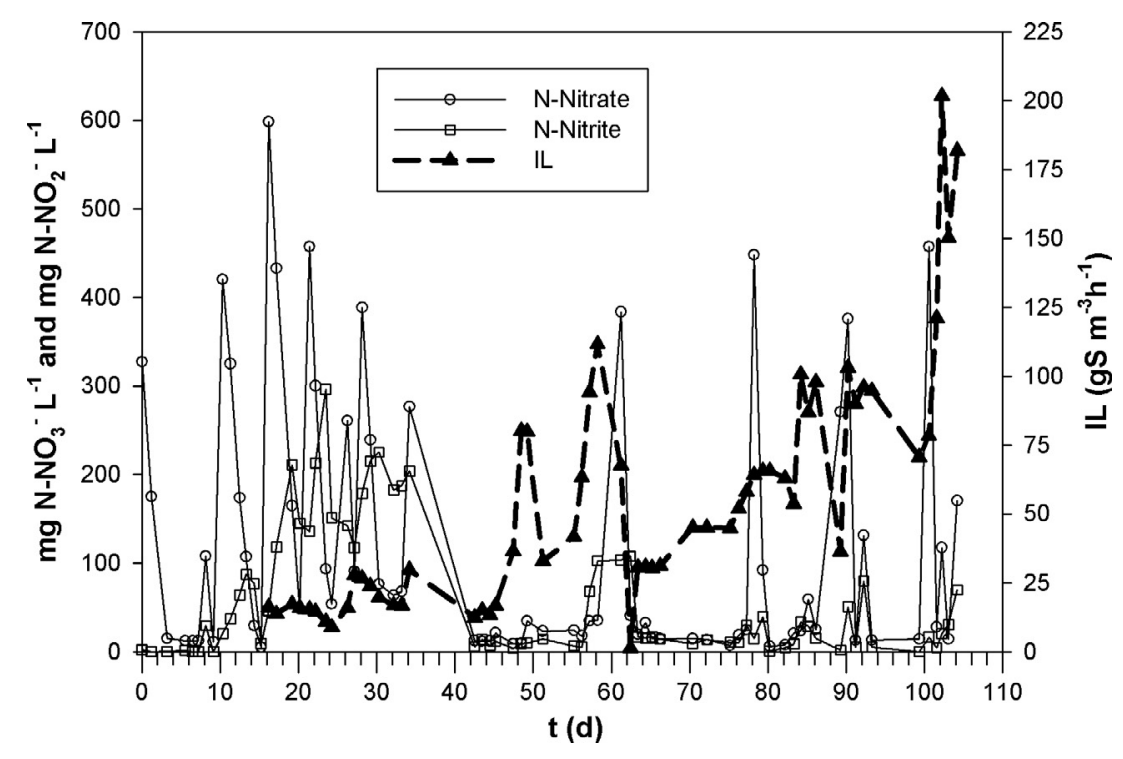

Fig. 2. Biotrickling filter evolution over the course of the experiment. (1) Manual regime for nitrate feeding, (2) controller regime for nitrate feeding. 
(a)

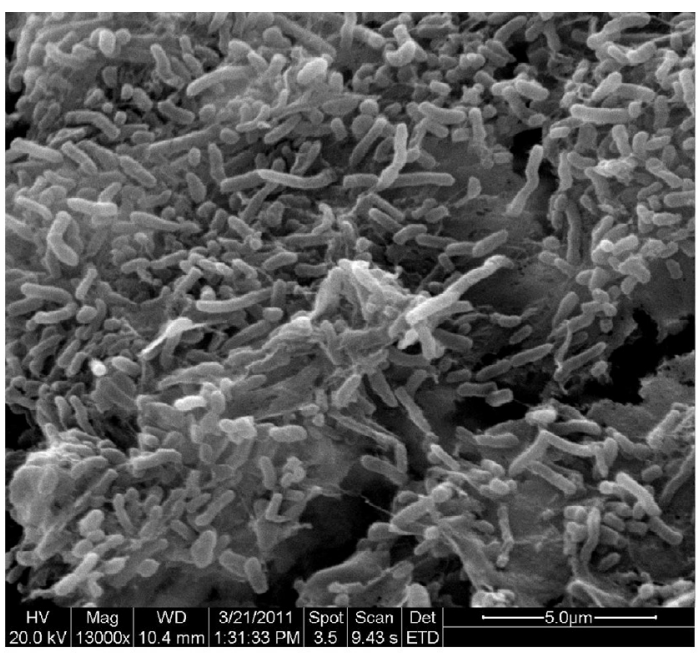

(b)

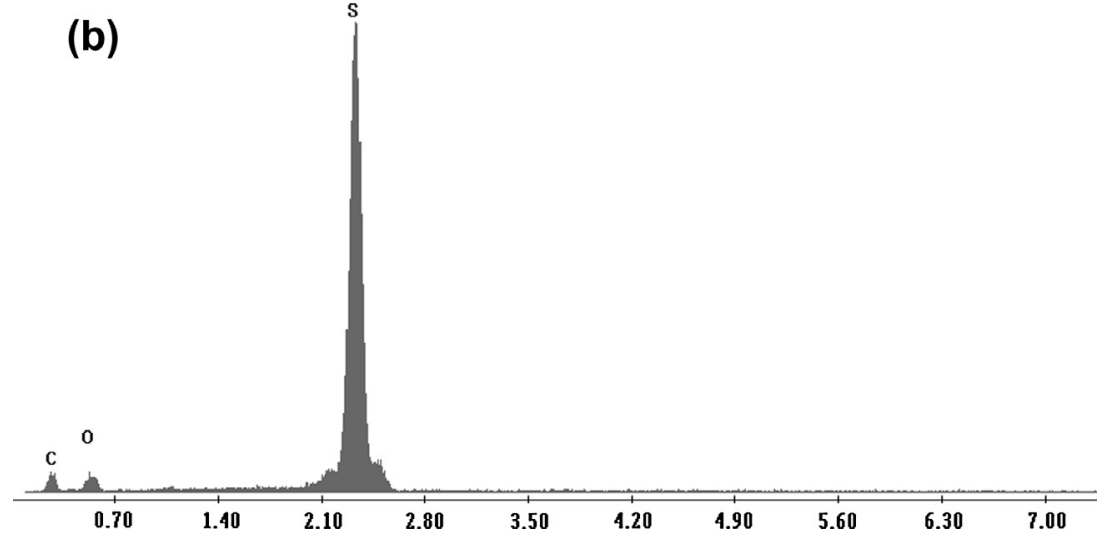

Fig. 3. (a) Image from scanning electron microscopy. (b) EDX analysis.

(EBRT $180 \mathrm{~s}$, TLV $4.7 \mathrm{~m} \mathrm{~h}^{-1}$, $\mathrm{pH} 4$ ) without methane reduction. This is an interesting option, but more information about elemental sulphur formation and long term operation is required.

The sulphate concentration was lower than $8 \mathrm{~g} \mathrm{~L}^{-1}$ throughout the test period. A sulphur mass balance was performed by substraction [24]. It is known that the ratio of $\mathrm{N}^{-\mathrm{NO}_{3}^{-}}$supplied versus $\mathrm{H}_{2} \mathrm{~S}$ removed affects the $\mathrm{S}^{-\mathrm{SO}_{4}} / \mathrm{S}^{0}$ ratio produced $[4,25]$. Partial $\mathrm{H}_{2} \mathrm{~S}$ oxidation to elemental sulphur is carried out at an N/S ratio of $0.4 \mathrm{~mol} \mathrm{~mol}^{-1}$ and complete $\mathrm{H}_{2} \mathrm{~S}$ oxidation to sulphate at an $\mathrm{N} / \mathrm{S}$ ratio of $1.6 \mathrm{~mol} \mathrm{~mol}^{-1}$ [7]. The biotrickling filter was running under nitrate limiting conditions at a low N/S ratio $\left(0.77 \pm 0.32 \mathrm{~mol} \mathrm{~mol}^{-1}\right)$, so elemental sulphur was the main oxidation product $(68.4 \pm 15.7 \%)$, with an $\mathrm{S}-\mathrm{SO}_{4} / \mathrm{S}^{0}$ ratio of 0.46 . Similar results were obtained by Soreanu et al. [6], who observed that $65 \%$ of the $\mathrm{H}_{2} \mathrm{~S}$ degraded was oxidised to elemental sulphur. On day 65 the N/S ratio was increased to $1.52 \mathrm{~mol} \mathrm{~mol}^{-1}$ and the elemental sulphur production diminished to $25.1 \%$, meaning that it is possible to control the oxidation ratio by altering the $\mathrm{N} / \mathrm{S}$ ratio. Montebello et al. [4] achieved an elemental sulphur production of $14 \%$ using OPUF at a similar high $\mathrm{N} / \mathrm{S}$ ratio of $1.46 \mathrm{~mol} \mathrm{~mol}^{-1}$.

\subsection{Effect of increasing TLV}

Six liquid flow rates $\left(20,40,80,120,160\right.$ and $\left.180 \mathrm{~L} \mathrm{~h}^{-1}\right)$ were studied and these correspond to TLVs of 2.3, 4.6, 9.1, 13.7, 18.3 and $20.6 \mathrm{~m} \mathrm{~h}^{-1}$, respectively. The $\mathrm{H}_{2} \mathrm{~S}$ RE values for the three constant $\mathrm{H}_{2} \mathrm{~S}$ IL values are shown versus the TLVs in Fig. 4. The EBRT was set at $144 \mathrm{~s}$ during the test period. As expected, it can be seen from Fig. 4 that the $\mathrm{H}_{2} \mathrm{~S}$ RE increased when the TLV was increased,

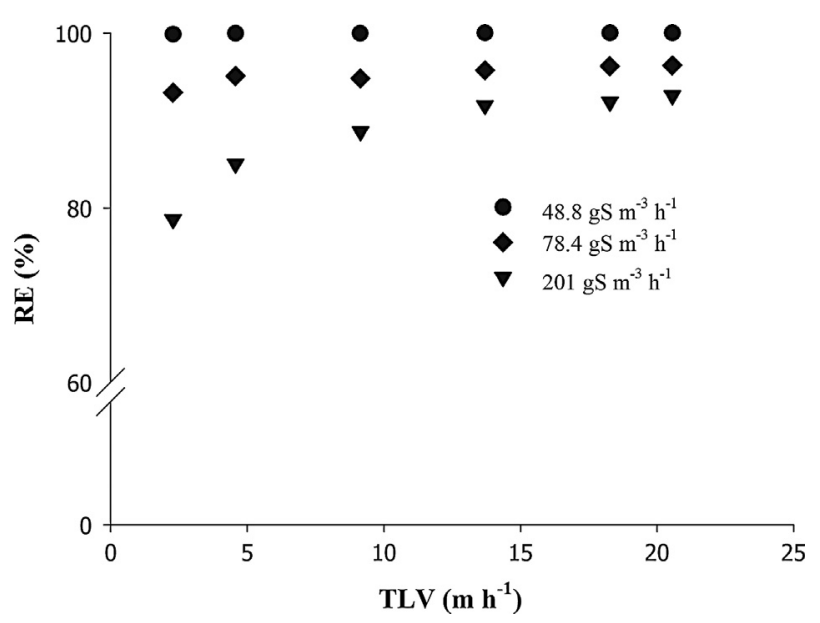

Fig. 4. Influence of TLV on $\mathrm{H}_{2} \mathrm{~S}$ removal efficiency (RE).

although the RE remained constant at $99.5 \pm 0.7 \%$ for $\mathrm{H}_{2} \mathrm{~S}$ IL values of less than $78 \mathrm{~g} \mathrm{~S} \mathrm{~m}^{-3} \mathrm{~h}^{-1}$. When working with an $\mathrm{H}_{2} \mathrm{~S}$ IL of $201 \mathrm{~g} \mathrm{~S} \mathrm{~m}^{-3} \mathrm{~h}^{-1}$, the RE began to decrease for TLVs lower than $15 \mathrm{~m} \mathrm{~h}^{-1}$, falling to less than $80 \%$ for a TLV of $2.3 \mathrm{~m} \mathrm{~h}^{-1}$. As a result, $15 \mathrm{~m} \mathrm{~h}^{-1}$ was fixed as the TLV minimum value.

The optimal TLV value in this study (above $15 \mathrm{~m} \mathrm{~h}^{-1}$ ) is higher than the values obtained previously by other authors in the aerobic biofiltration of $\mathrm{H}_{2} \mathrm{~S}$ from biogas using Pall rings [26], OPUF (1$\left.5 \mathrm{~m} \mathrm{~h}^{-1}\right)$ and HD Q-PAC ${ }^{\circledR}\left(2.4 \mathrm{~m} \mathrm{~h}^{-1}\right)$ [5], a 1:8 mixture of plastic 
rings and coconut fibre (range $2.4-7.1 \mathrm{~m} \mathrm{~h}^{-1}$, optimal $4.0 \mathrm{~m} \mathrm{~h}^{-1}$ ) [23] and coconut fibre $\left(3.6 \mathrm{~m} \mathrm{~h}^{-1}\right)$ [21] as carriers.

Poor water dispersion was observed at low TLV (below $5 \mathrm{~m} \mathrm{~h}^{-1}$ ) due to the liquid distribution system used. This indicates that the mass transfer between the gas phase and the liquid/biofilm phase was deficient. It is very likely that on an industrial scale the use of an efficient liquid distribution system, such as a tray distributor, would allow operation at lower TLV values without RE loss.

The pressure drop in this study was constant at $1 \mathrm{~mm}$ of the water column, even with a TLV value of $21 \mathrm{~m} \mathrm{~h}^{-1}$. In contrast, Fernández et al. observed a pressure drop of $12 \mathrm{~mm}$ of the water column at a TLV of $21 \mathrm{~m} \mathrm{~h}^{-1}$ when the filter was operated with OPUF under the same conditions (data not published). The low pressure drop observed in this study represents a major advantage of this packing material for an industrial application, because the pressure drop is directly related to efficient blower operation and energy costs [27].

\subsection{Estimation of mass transfer coefficients}

The biogas composition used in these calculations was $68 \pm 3 \%$ $\mathrm{v} / \mathrm{v} \mathrm{CH} \mathrm{CH}_{4}$ and $26 \pm 2 \% \mathrm{v} / \mathrm{v} \mathrm{CO}_{2}$, and the recirculation medium was assumed to be pure water.

Fig. 5 shows the proportional increase in $K_{\mathrm{L}}$ with an increase in TLV up to $K_{\mathrm{L}}$ values of $4.98 \times 10^{-5} \mathrm{~m} \mathrm{~s}^{-1}$ for the maximum TLV used in the study $\left(21 \mathrm{~m} \mathrm{~h}^{-1}\right)$. The value of $K_{\mathrm{G}}$ was $2.78 \mathrm{~K} \mathrm{~mol}$ $\mathrm{m}^{-2} \mathrm{~h}^{-1} \mathrm{~atm}^{-1}$.

Dorado et al. [28] used a TLV value of $2 \mathrm{~m} \mathrm{~h}^{-1}$, i.e. similar to the lowest TLV used in this study $\left(2.3 \mathrm{~m} \mathrm{~h}^{-1}\right)$, and obtained $K_{\mathrm{L}}$ values of a similar order $\left(1.06 \times 10^{-6} \mathrm{~m} \mathrm{~s}^{-1}\right)$ to those reported here $\left(1.15 \times 10^{-5} \mathrm{~m} \mathrm{~s}^{-1}\right)$ using lava rock as a carrier (with a similar superficial area of $377 \mathrm{~m}^{2} \mathrm{~m}^{-3}$ ) and the Onda equation to estimate $K_{\mathrm{L}}$.

\subsection{Influence of increasing $\mathrm{H}_{2} \mathrm{~S}$ inlet concentration}

The RE decreased to $85 \%$ when the $\mathrm{H}_{2} \mathrm{~S}$ IL was greater than $180 \mathrm{~g} \mathrm{~S} \mathrm{~m}^{-3} \mathrm{~h}^{-1}$. This decrease in RE could be due to inhibition caused by substrate accumulation in the recirculation medium. However, the ORP values were higher than $-173 \mathrm{mV}$ and a limitation caused by biological capacity or $\mathrm{H}_{2} \mathrm{~S}$ mass transfer to the biofilm is therefore more feasible. The sensitivity of NR-SOB to the higher $\mathrm{H}_{2} \mathrm{~S}$ inlet concentration was previously reported by $\mathrm{McCo}-$ mas et al. [29]. The use of an $\mathrm{H}_{2} \mathrm{~S}$ IL of less than $120 \mathrm{~g} \mathrm{~S} \mathrm{~m}^{-3} \mathrm{~h}^{-1}$ was suggested to maintain RE values over $99 \%$ (Fig. 6). The critical EC reached in this study $\left(120 \mathrm{~g} \mathrm{~S} \mathrm{~m}^{-3} \mathrm{~h}^{-1}\right)$ was similar to the value

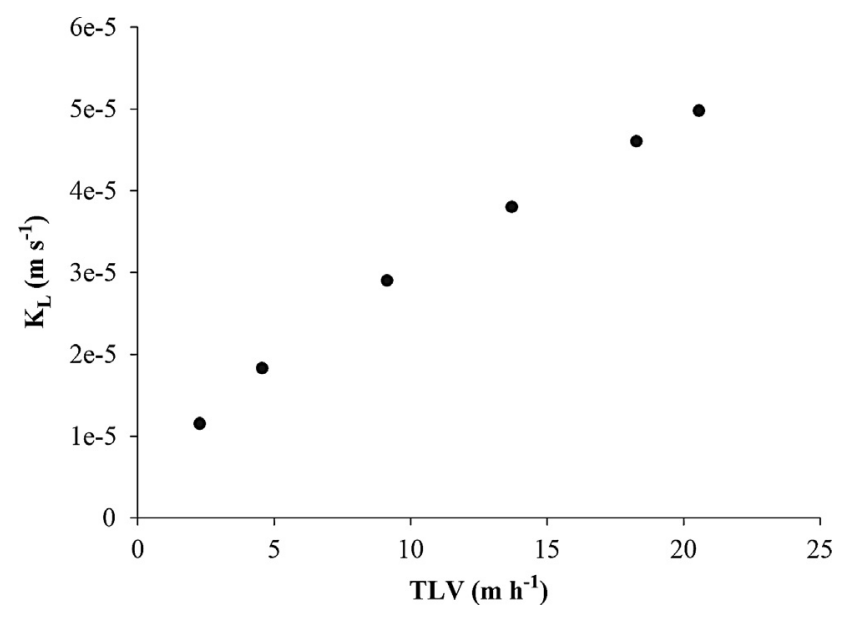

Fig. 5. Plot of $K_{\mathrm{L}}$ versus TLV.

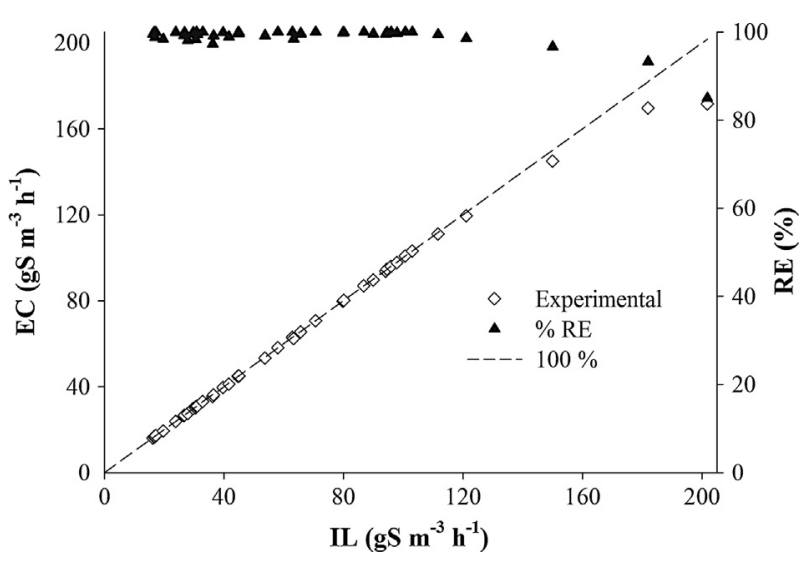

Fig. 6. Influence of $\mathrm{H}_{2} \mathrm{~S}$ inlet load (IL) on biofilter elimination capacity (EC).

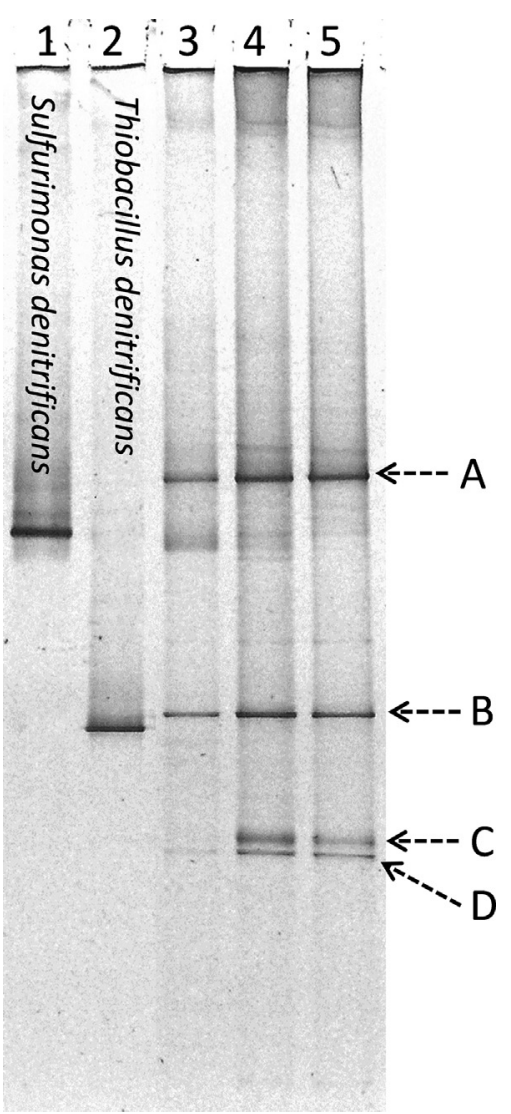

Fig. 7. DGGE banding patterns. Lanes 1 and 2: pure strains of Sulfurimonas denitrificans (DSM 1251) and Thiobacillus denitrificans (DSM 12475), 3: recirculation medium, 4: sample carrier from bottom, 5: carrier sample from top.

obtained by Montebello et al. [4] on using OPUF and the same bacteria population ( $100 \mathrm{~g} \mathrm{~S} \mathrm{~m}^{-3} \mathrm{~h}^{-1}$ ). Fernández et al. [10] found critical EC values that were two times lower with the same bacteria population immobilised in OPUF and a manual nitrate feed. Another study on the anoxic biofiltration of $\mathrm{H}_{2} \mathrm{~S}$ from biogas in a biotrickling filter gave an $\mathrm{EC}_{\max }$ of $50 \mathrm{~g} \mathrm{~S} \mathrm{~m}^{-3} \mathrm{~h}^{-1}$ [30]. These differences could be explained by the process being more stable and less sensitive to overloads when using a controlled nitrate feeding regime.

Tomas et al. [26] employed the same carrier (polypropylene Pall rings) and obtained similar maximum EC values (170 $\mathrm{g} \mathrm{S} \mathrm{m}^{-3} \mathrm{~h}^{-1}$ ) during the aerobic biofiltration of $\mathrm{H}_{2} \mathrm{~S}$ from biogas with an EBRT of 3 min. However, similar studies performed by Fortuny et al. [5] 
gave greater maximum EC values of 280 and $250 \mathrm{~g} \mathrm{H}_{2} \mathrm{~S} \mathrm{~m}^{-3} \mathrm{~h}^{-1}$ for two different lab-scale reactors, with OPUF and HQ-PAQ used as carriers and EBRTs of 2.8 and 3 min, respectively, although the critical EC values were comparable to those achieved in this study $\left(140 \mathrm{~g} \mathrm{~S} \mathrm{~m}^{-3} \mathrm{~h}^{-1}\right)$. The results obtained by Charnnok et al. [23] were also similar to those obtained in this study, with EC values of $150.3 \pm 21.2 \mathrm{~g} \mathrm{~S}^{-} \mathrm{H}_{2} \mathrm{~S} \mathrm{~m}^{-3} \mathrm{~h}^{-1}(97.3 \pm 4.2 \%)$ at an EBRT $3 \mathrm{~min}$, TLV $4.7 \mathrm{~m} \mathrm{~h}^{-1}$ and pH 4.0. However, Chaiprapat et al. [21] obtained a higher maximum EC $\left(220 \mathrm{~g} \mathrm{~S} \mathrm{~m}^{-3} \mathrm{~h}^{-1}\right)$ than in this study, although the $\mathrm{RE}$ was lower $(\mathrm{RE} \approx 40 \%$ ).

\subsection{DGGE analysis}

The sample obtained from the recirculation medium (lane 3 ) in DGGE gel showed three highlighted bands (3A, 3B and 3D), similar to the samples obtained from the carrier at the bottom (4A, 4B and 4D) and the top of the biotrickling filter (5A, 5B and 5D) (Fig. 7). One new highlighted band was also observed in the carrier ( $4 \mathrm{C}$ and $5 \mathrm{C}$ ), which suggests the presence of bacteria populations that grew only in the biofilm. The similarity between the bands of the samples taken from the bottom and top of the biofilters (lanes 4 and 5) suggests the establishment of the same populations throughout the packed bed.

Pure cultures of Sulfurimonas denitrificans ATCC 33889 and Thiobacillus denitrificans DSM 12475 were analysed in lanes 1 and 2 . These cultures were chosen as they have previously been reported in similar ambient conditions $[6,31,32]$. The biofilter samples (lines 3,4 and 5) did not have bands similar to those of the pure cultures of lines 1 and 2. This finding indicates that other NR-SOB cultures are present in the biofilm. Further investigations will be required to determine the strain types by DNA sequencing.

\section{Conclusions}

It has been shown that Pall rings can be used as a packing material in an anoxic biotrickling filter to remove $\mathrm{H}_{2} \mathrm{~S}$ from biogas without a reduction in methane concentration. Thus, for methane pipeline grade quality production the anoxic biofiltration is a more feasible technology as a pretreatment for $\mathrm{H}_{2} \mathrm{~S}$ removal than the more commonly used aerobic biotrickling filters.

Nitrate solution can be added efficiently by ORP measurement and, this control mode allows the anoxic biotrickling filters to be controlled efficiently and at low cost.

The low pressure drop (constant at $1 \mathrm{~mm}$ of the water column) allows a significant reduction in the energy cost of the blower. An $\mathrm{RE}$ of $99 \%$ was achieved for $\mathrm{H}_{2} \mathrm{~S}$ IL values lower than $120 \mathrm{~g} \mathrm{~S} \mathrm{~m}^{-3}$ $\mathrm{h}^{-1}$ using a controlled nitrate feeding regime and a TLV of $15 \mathrm{~m} \mathrm{~h}^{-1}$. The maximum EC achieved under these conditions was $170 \mathrm{~g} \mathrm{~S} \mathrm{~m}^{-3} \mathrm{~h}^{-1}$.

\section{Acknowledgements}

The authors wish to express their sincere gratitude to the Spanish Ministry of Science and Innovation and the European FEDER funds for providing financial support through the projects CTM2009-14338-C03-02 and UNCA08-1E-003. The authors would also like to thank the Iberoamerican Ph.D. Program in Sciences of the University of Cádiz, and the Heineken brewery located in Jaén (Spain) for providing the granular sludge needed for biogas production.

\section{References}

[1] M. Syed, G. Soreanu, P. Falletta, M. Béland, Removal of hydrogen sulfide from gas streams using biological processes - a review, Can. Biosyst. Eng. 48 (2006) $2.1-2.14$
[2] N. Abatzoglou, S. Boivin, A review of biogas purification processes, Biofuel. Bioprod. Bior. 3 (2009) 42-71.

[3] G. Soreanu, M. Beland, P. Falletta, B. Ventresca, P. Seto, Evaluation of different packing media for anoxic $\mathrm{H}_{2} \mathrm{~S}$ control in biogas, Environ. Technol. 30 (2009) 1249-1259.

[4] A.M. Montebello, M. Fernández, F. Almenglo, M. Ramírez, D. Cantero, M. Baeza, D. Gabriel, Simultaneous methylmercaptan and hydrogen sulfide removal in the desulfurization of biogas in aerobic and anoxic biotrickling filters, Chem. Eng. J. 200-202 (2012) 237-246.

[5] M. Fortuny, J.A. Baeza, X. Gamisans, C. Casas, J. Lafuente, M.A. Deshusses, D. Gabriel, Biological sweetening of energy gases mimics in biotrickling filters, Chemosphere 71 (2008) 10-17.

[6] G. Soreanu, M. Béland, P. Falletta, K. Edmonson, P. Seto, Laboratory pilot scale study for $\mathrm{H}_{2} \mathrm{~S}$ removal from biogas in an anoxic biotrickling filter, Water Sci. Technol. 57 (2008) 201-207.

[7] G. Soreanu, M. Béland, P. Falletta, K. Edmonson, P. Seto, Investigation on the use of nitrified wastewater for the steady-state operation of a biotrickling filter for the removal of hydrogen sulphide in biogas, J. Environ. Eng. Sci. 7 (2008) $543-552$.

[8] S. Colle, D. Thomas, J. Vanderschuren, Process simulation of sulphur dioxide abatement with hydrogen peroxide solutions in a packed column, Chem. Eng. Res. Des. 83 (2005) 81-87.

[9] D. Gabriel, M. Deshusses, Retrofitting existing chemical scrubbers to biotrickling filters for $\mathrm{H}_{2} \mathrm{~S}$ emission control, Proc. Natl. Acad. Sci. USA 100 (2003) 6308-6312.

[10] M. Fernández, M. Ramírez, R.M. Pérez, R. Rovira, D. Gabriel, J.M. Gómez, D. Cantero, Hydrogen sulfide $\left(\mathrm{H}_{2} \mathrm{~S}\right)$ removal from biogas using biofiltration under anoxic conditions, in: M. Deshusses, S. Revah (Eds.) DUKE-UAM Conference on Biofiltration for Air Pollution Control, DUKE-UAM, Washington, DC, 2010, pp. $148-154$.

[11] M. Ramirez, J.M. Gomez, G. Aroca, D. Cantero, Removal of hydrogen sulfide by immobilized Thiobacillus thioparus in a biotrickling filter packed with polyurethane foam, Bioresour. Technol. 100 (2009) 4989-4995.

[12] A.J.H. Janssen, S. Meijer, J. Bontsema, G. Lettinga, Application of the redox potential for controlling a sulfide oxidizing bioreactor, Biotechnol. Bioeng. 60 (1998) 147-155.

[13] E.A. Greene, C. Hubert, M. Nemati, G.E. Jenneman, G. Voordouw, Nitrite reductase activity of sulphate-reducing bacteria prevents their inhibition by nitrate-reducing, sulphide-oxidizing bacteria, Environ. Microbiol. 5 (2003) 607-617.

[14] K. Onda, H. Takeuchi, Y. Okumoto, Mass transfer coefficients between gas and liquid phases in packed columns, J. Chem. Eng. Jpn. 1 (1968) 5662.

[15] 11B2 Viscosity of Defined Gaseous Hydrocarbon Mixtures, in: API Technical Data Book - Petroleum Refining, sixth ed., American Petroleum Institute, Washington, DC, 1997.

[16] R.C. Weast, Handbook of Chemistry and Physics, 55th ed., CRC Press, Cleveland, 1974.

[17] R.C. Reid, J.M. Prausnitz, B.E. Poling, The properties of Gases \& Liquids, Fourth ed., McGraw-Hill, Inc., New York, 1987.

[18] A. Tamimi, E.B. Rinker, O.C. Sandall, Diffusion coefficients for hydrogen sulfide, carbon dioxide, and nitrous oxide in water over the temperature range 293368 K, J. Chem. Eng. Data 39 (1994) 330-332.

[19] J.M. Gómez, D. Cantero, C. Webb, Immobilisation of Thiobacillus ferrooxidans cells on nickel alloy fibre for ferrous sulfate oxidation, Appl. Microbiol. Biotechnol. 54 (2000) 335-340.

[20] L.S. Clesceri, A.E. Greenberg, A.D. Eaton, Standard Methods for the Examination of Water and Wastewater, 20 ed., American Public Health Association, Washington, DC, 1999.

[21] S. Chaiprapat, R. Mardthing, D. Kantachote, S. Karnchanawong, Removal of hydrogen sulfide by complete aerobic oxidation in acidic biofiltration, Process Biochem. 46 (2011) 344-352.

[22] G. Rodriguez, A.D. Dorado, A. Bonsfills, R. Sanahuja, D. Gabriel, X. Gamisans, Optimization of oxygen transfer through venturi-based systems applied to the biological sweetening of biogas, J. Chem. Technol. Biotechnol. 87 (2012) 854 860.

[23] B. Charnnok, T. Suksaroj, P. Boonswang, S. Chaiprapat, Oxidation of hydrogen sulfide in biogas using dissolved oxygen in the extreme acidic biofiltration operation, Bioresour. Technol. (2012). http://dx.doi.org/10.1016/ j.biortech.2012.12.114.

[24] A.J.H. Janssen, S.C. Ma, P. Lens, G. Lettinga, Performance of a sulfide-oxidizing expanded-bed reactor supplied with dissolved oxygen, Biotechnol. Bioeng. 53 (1997) 32-40.

[25] A.J. Wang, D.Z. Du, N.Q. Ren, J. Van Groenestijn, An innovative process of simultaneous desulfurization and denitrification by thiobacillus denitrificans, J. Environ. Sci. Health, Part A 40 (2005) 1939-1949.

[26] M. Tomas, M. Fortuny, C. Lao, D. Gabriel, F.J. Lafuente, X. Gamisans, Technical and economical study of a full-scale biotrickling filter for $\mathrm{H}_{2} \mathrm{~S}$ removal from biogas, Water Pract. Technol. 4 (2009) 026.

[27] D. Gabriel, M.A. Deshusses, Technical and economical analysis of the conversion of a full-scale scrubber to a biotrickling filter for odour control, Water Sci. Technol. 50 (2004) 309-318.

[28] A.D. Dorado, G. Rodriguez, G. Ribera, A. Bonsfills, D. Gabriel, J. Lafuente, X. Gamisans, Evaluation of mass transfer coefficients in biotrickling filters: experimental determination and comparison to correlations, Chem. Eng. Technol. 32 (2009) 1941-1950. 
[29] C. McComas, K.L. Sublette, G. Jenneman, G. Bala, Characterization of a novel biocatalyst system for sulfide oxidation, Biotechnol. Progr. 17 (2001) 439446.

[30] G. Soreanu, P. Falleta, P. Seto, Process optimization of H2S removal from biogas in an anoxic biotrickling filter, in Proceeding of IWA World Water Congress and Exhibition, Montreal, Canada, 2010, paper\#IWA-2653.
[31] J. García de Lomas, A. Corzo, J.M. Gonzalez, J.A. Andrades, E. Iglesias, M.J. Montero, Nitrate promotes biological oxidation of sulfide in wastewaters: experiment at plant-scale, Biotechnol. Bioeng. 93 (2006) 801-811.

[32] R. Kleerebezem, R. Mendez, Autotrophic denitrification for combined hydrogen sulfide removal from biogas and post-denitrification, Water Sci. Technol. 45 (2002) 349-356. 